\title{
Collaboratively Teaching Intellectual Freedom to Education Students
}

By Nadean Meyer and Darcy Bradley

\begin{abstract}
Together an education librarian and education professor developed a series of exercises for education students about intellectual freedom and book challenges. The resources are primarily online and they progressively work from book censorship cases and concerns to handling book challenges proactively through discussions, activities, and role playing. The education librarian offers realistic information and research expertise for an issue that is sometimes overlooked.
\end{abstract}

Intellectual freedom and book censorship are not often addressed in state standards for educators or the Common Core Standards (Common, n.d.) nor are questions about these topics likely found on current teacher competency tests such as the Praxis II (Reading, 2009). However, the past twenty years of American Library Association (ALA) statistics show overwhelmingly that book challenges most often appear in schools and are initiated by parents (American Library Association, 2011). Current teacher candidates can feel vulnerable to questions from parents regarding their book choices. These level one teachers are often unaware of the history of book challenges and do not know how to handle them. At some point in their teaching lives, these teacher candidates are likely to select some resources that will be objectionable to parents, colleagues, or administrators.

In these constricted educational times, it is not enough for teachers to love books and reading. They also need to be prepared to be proactive and competent in what "right to read" means. Through several collaborative class experiences, the authors developed a process to help teacher candidates in a young adult literature class learn about intellectual freedom and deal with book challenges. When the class is told that they are going to explore intellectual freedom and book censorship, they ask, "What is intellectual freedom?, What is book censorship?, and What do I do when a parent complains about my book choice?" Those questions begin our conversation with our students.

The class, Literature and Literacy for Young Adults, is required as part of the teacher certification process for reading majors and minors. We developed a unit to make teacher candidates aware of their and their students' rights as readers, to help them begin to understand the politics behind book censorship, and to employ the most effective ways to face these challenges. As reading majors, these teacher candidates take up to three courses on children's and young adult literature. They often rediscover their love of reading as they can choose what they read, and explore what it means to be "teachers as readers" as well as "teachers of readers." These new teachers read diverse titles such as Sherman Alexie's The Absolutely True Diary of a Part-time Indian, Rick Riordan's Percy Jackson series, manga titles, numerous memoirs by Chris Crutcher, Lois Lowry, and Roald Dahl, as well as other books that make the rounds through word-of-mouth, book talks, and free-wheeling book discussions.

When Darcy, a new faculty member joined the teacher education department of our university to teach the Literature and Literacy for Young Adults class, she contacted Nadean to help her explore the topic of intellectual freedom and censorship with her teacher candidates. Darcy explained that in her teaching experience, no one had ever questioned or challenged her choice of books or texts for her classes. She knew that American classics such as Huckleberry Finn and Catcher in the Rye were on lists of books that had been challenged and authors such as Judy Blume, Robert Cormier and Chris Crutcher regularly appeared on challenged lists as well. Uncertain how to approach this topic with teacher candidates, Darcy thought it was natural to work with the education librarian on this unit. Nadean, as subject librarian for education faculty, has worked in area schools, both elementary and secondary, as a school librarian and has experience with book challenges. We met to plan and organize student experiences around intellectual freedom for Darcy's class taught each quarter. We wanted not only to educate future teachers about this topic, but to help them cope with 
parents or other adults questioning, or challenging their book choices. We have collected our resources in a research guide (http://research.ewu.edu/ya tab of Intellectual Freedom) and website that provide open access for most of the items we use (http://sites.google.com/site/onlineintellectualfreedom).

\section{Starting with Questions, Moving to Experiences}

We start our introduction to the topic by building on the students' prior knowledge from another children's literature class which distributes Daniel Pennac's The Rights of the Reader (2006). The students are enthralled by these rights, in particular number five "the right to read anything." They appear to be unaware of the concepts and big ideas behind that belief. Our goal is to help our students understand the complexities behind Pennac's seemingly simple statements. We begin with several online sites that have self-correcting quizzes on the First Amendment and book challenges (Teach First Amendment, Kids Speak Online, First Amendment Center, Illinois First Amendment, see references). Almost everyone learns more than they expected from taking some of these quizzes. Often cries of outrage erupt when they discover a favorite childhood book was challenged or censored. Definitions of key terms in a book challenge (ALA, n.d.) and a simple chart of the connection between the U.S. Constitution and Freedom to Read keep the focus on big ideas (Meyer, 2007). This first session presents information in an interactive manner, and allows us to gauge the level of knowledge about intellectual freedom and right to read issues. We often end this session by asking students to pose their current questions about book censorship, which typically focus on what books are banned and why.

\section{Using Challenged Authors and Their Books}

We progress to more specific applications of the right to read with particular books. Chris Crutcher, who lives in our hometown of Spokane, holds the distinction of being a frequently challenged author for teens. As a graduate of our university, he often visits our class to answer questions about being a writer, his books, and book challenges. Crutcher eloquently speaks for teens in his work and when he speaks to educators. He passionately explains why teens need to read about troubling situations and why his characters sometimes swear. Students are expected to read at least one of his novels or his autobiography as a part of their independent reading assignment. They are divided into literature circle groups in which we encourage discussion and ask questions such as

- Why would teens read this book?

- What topics could be challenged in this book?

- How could you use this book in your reading program and your classroom?

This experience engenders ardent discussions around themes such as untimely or unfair death, narrow-minded people, child abuse and neglect, peer pressure and the use/misuse of adult authority, and finding yourself. From an edited compilation of letters to well-known authors for teens (Dear Author, 2007) we read aloud letters from a sexually abused teenage girl to Chris Crutcher and his responses to her. The poignancy of this one teen's situation and how Crutcher's book helped her reminds students why supporting students' right to read can be powerful for an individual reader. While we use face-to-face discussion in the class session, this conversation could also take place online on a forum or via web conferencing software. No matter the venue, these discussions help our teacher candidates understand how background experiences shape the meanings constructed from books (Rosenblatt 1994). When confronted with a variety of viewpoints within our class, these teacher candidates begin to comprehend why someone might object to a book and they begin to think more proactively. Chris Crutcher's website (http://chriscrutcher.com) becomes a stepping stone for students to find information about censorship because they acquired experience with his books. The website includes details about his titles that have been challenged and excellent web links to valuable resources for educators.

\section{Gathering Information}

Moving from Crutcher's helpful website, we look at a range of web sites. For example, students can examine ALA's annual reported book challenge list (http://www.ala.org/ala/issuesadvocacy/banned/frequentlychallenged/index.cfm ), the Online Book Banned list 
(http://onlinebooks.library.upenn.edu/banned-books.html), the Parents Against Bad Books in Schools (PABBIS) (http://www.pabbis.com/) website and more. A general question to the group regarding which controversial topics some adults do not want teens to read about brings up major ones: sex-sexuality-gender, religion, profanity-swearing, drugs and alcohol, and the catchall phrases such as "not age-appropriate" or against "family values." The online lists and paper copies of the reports from The Newsletter on Intellectual Freedom (also online in several databases such as ProQuest Research Library) seem to allow broader discussions about particular issues and they draw out personal stories from the teacher candidates as well. Additionally when we introduce students to the Newsletter, they learn they can access it through public libraries at any time in their career. All students now have a wealth of detail from the readings and online explorations. Next, we move to responding to a challenge.

\section{Trying Out What You Learned}

To promote engagement, we used authentic stories for case studies or scenarios. The narratives allow students to put themselves in the place of a teacher who chose to use a certain book, then faced a challenge from a parent. These scenarios naturally lead to discussion about best practices when working with parents and when a book challenge is attempted. Since the narratives are discussed in groups, it allows the teacher candidate who has developed a good grasp about the concept of intellectual freedom to help those who are still a bit skeptical and unsure. Additional scenarios are available in a recent book by Pat Scales (Scales, 2009).

We move naturally to information on how to prepare for possible book challenges. Over several quarters of work together we developed a more interactive way to help teacher candidates understand levels of challenges. Using the ALA severity of actions definitions list, we cut each level into a strip (Table 1, Figure 1).

Table 1: Book Challenges - Level of Severity and Possible Reactions

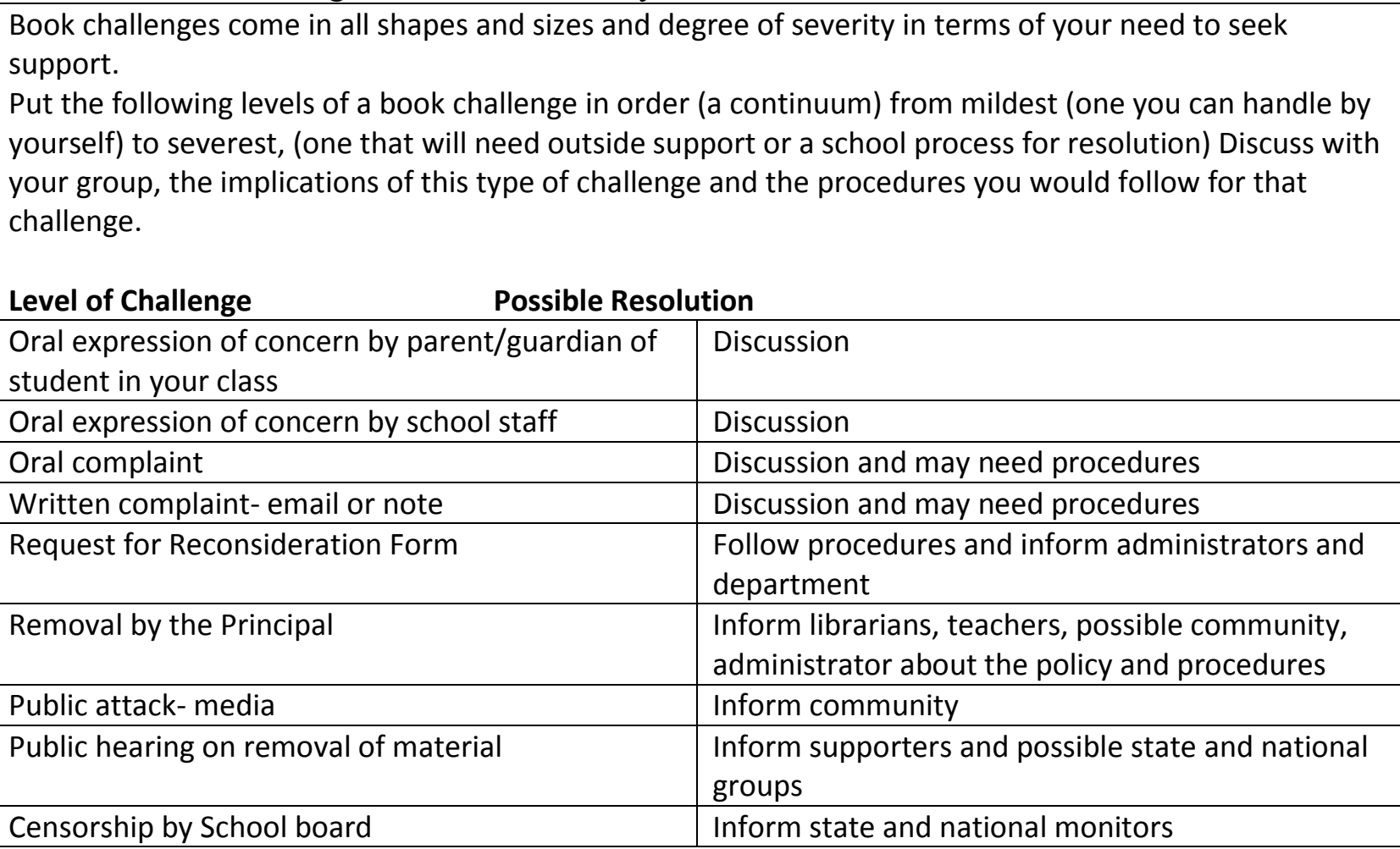

In small groups, students attempt to put the strips in order from most to least severe action by discussing what kind of assistance they would require in dealing with a challenge. These discussions reveal misunderstandings about how teachers should respond. For example, there are significant differences between responding to parents worried about their own child than to parents who want changes a unit of study or curriculum for everyone. 
Figure 1

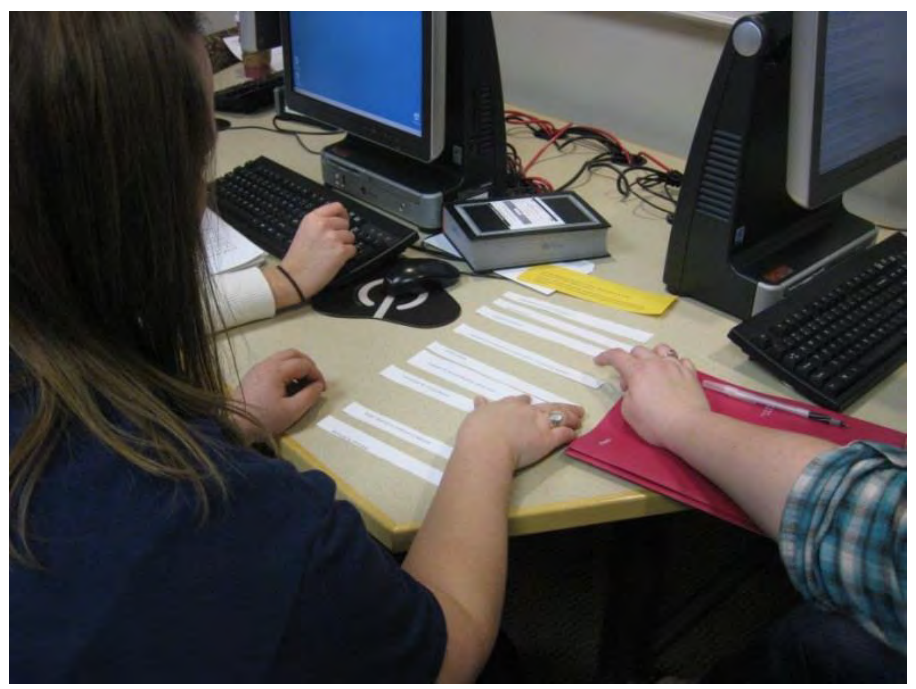

At this point in their education, many of our teacher candidates believe that principals have the final say on almost everything. Thus, it is important to talk about subject departments, district curriculum policies, professional organizations, and working as subject or grade level teams. This activity to recognize the level of challenge and its degree of seriousness beyond a classroom clarifies the distinguishing factors between a question of concern and true censorship.

Role playing is used to promote dealing with emotions and affective learning. The giggles from the teacher candidates that accompany this activity indicate a degree of nervousness. We lead a discussion on challenging customers or clients in order to remind them what they already know about resolving conflicts. These role plays can help the student understand how to use appropriate words and actions in potentially uncomfortable communications (Clapper, 2010). The process of thinking through what to say and do prior to an actual book challenge situation is effective, and reinforces our goal of preparing future teachers for book challenges.

Groups of three to five students read the examples and we give them practical advice for effective role play steps (van Ments, 1999). Then we model one example, drawing in at least one student to assist us. Next, we roam the room to listen to or interact with the groups; this shows us different levels of comfort about their role plays (Figure 2).

Figure 2

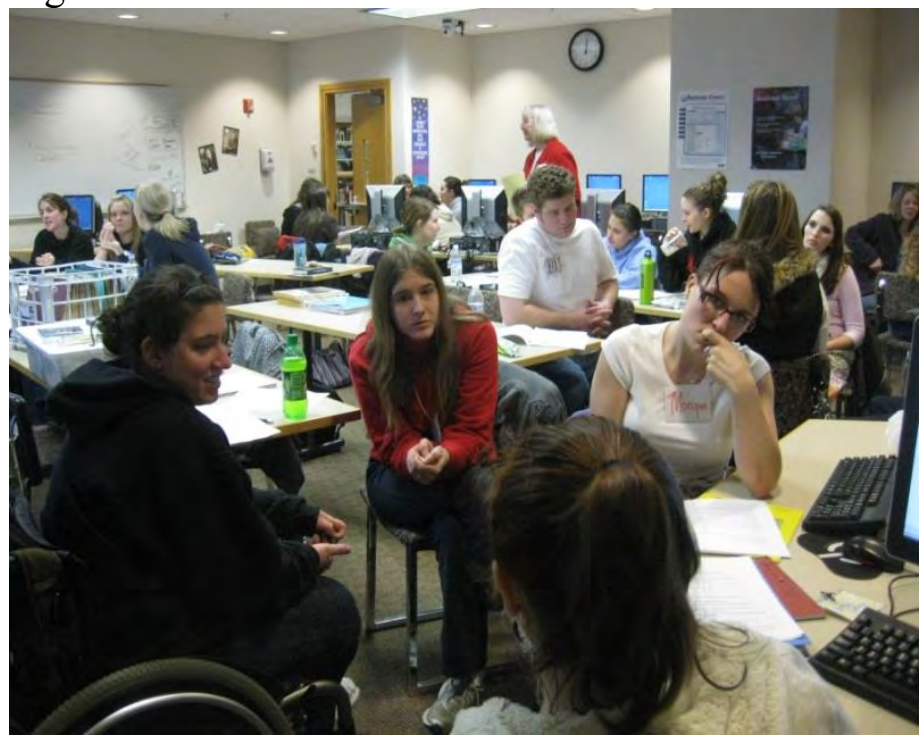


All groups share their scenarios before the entire class. It is common to see the role plays mentioned as a valuable part of this experience. During debriefing of the role plays, we can gently suggest common procedures of de-escalating the situation, such as having another person with you or setting up a time for further discussion. A future step would be to videotape some of the groups and put their role plays online for discussion (Figure 3).

Figure 3

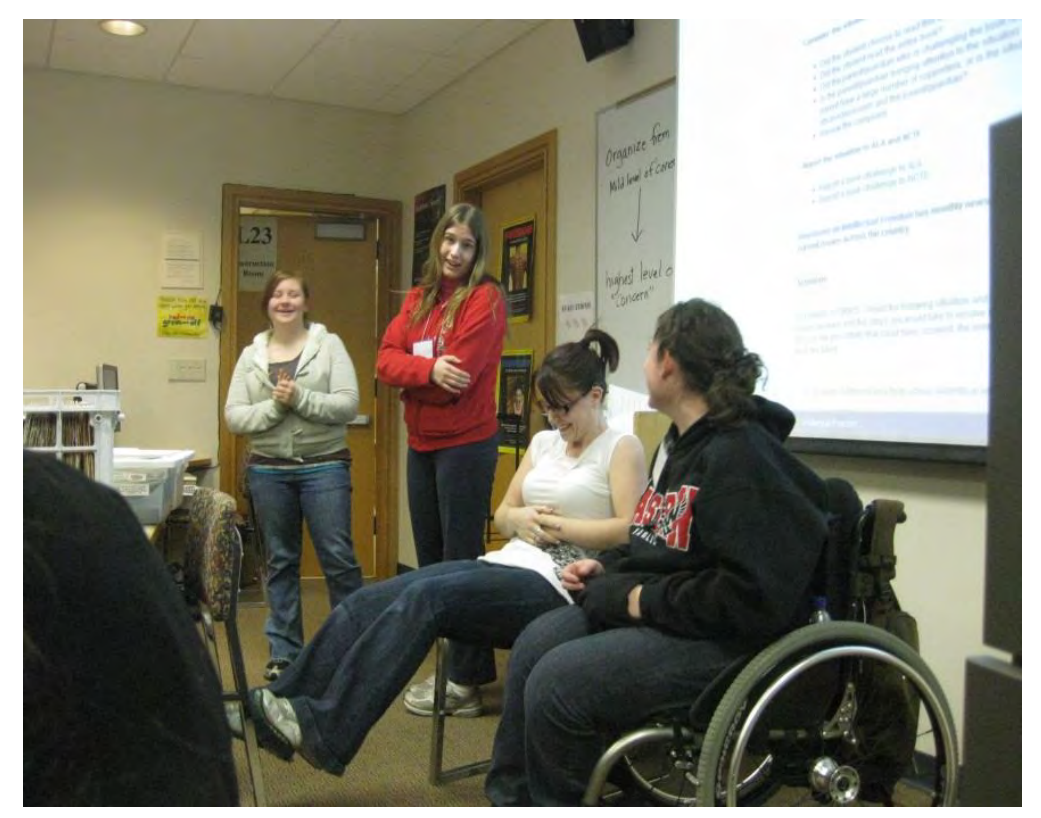

\section{Planning for Possible Book Challenges}

While teachers and teacher candidates are familiar with writing lesson plans, they do not always plan ahead to deal effectively with potentially controversial topics. We show teacher candidates how to manage challenges through the professional groups that support teachers and librarians, and we share the National Council of Teachers of English (NCTE) process of writing a book rationale (2010). We steer them towards successful methods such as Pat Scale's parent-child discussion groups of controversial books in middle schools called "Communicate through Literature" (Sutton, 2008, p.496) or Multnomah County Library's Banned Book Assemblies in schools to start discussions with picture books (Kastner \& Allen, 2002).

Classes run two days and allow students time to reflect and discuss outside of class. Activities and experiences help clarify some of the misunderstandings and in fact, change some minds as well as develop the kind of courage that comes from actual knowledge about book challenges.

\section{Teaching Collaboratively}

The American Library Association (ALA) Code of Ethics asserts that a librarian's duty is to support and advocate the Freedom to Read. The second tenet states, "We uphold the principles of intellectual freedom and resist all efforts to censor library resources" (ALA, 2008). Librarians working in all types of venues learn the concept and principles of intellectual freedom through their coursework and professional duties. Yet youth and school librarians sometimes discover inconsistencies between their support of the child's right to read and other adults - parents, guardians, teachers and administrators--who question reading and ideas expressed in books. Intellectual freedom and the role of freedom to read have not necessarily been part of teacher or principal education programs. Youth and education librarians are therefore obligated to present the topic and teach other adults about intellectual freedom, and demonstrate positive educational experiences for students by supporting their right to read (Adams, 2011; Adams, 2009; Maycock, 2011). 
Shared teaching works for us because the class instructor knows her students well by the time we introduce this topic, and the librarian's expertise in this area is recognized. Students have met Nadean through general library instruction and for help on particular assignments before this session. That level of familiarity encourages candid questions from the teacher candidates. The ideas and interactive activities about intellectual freedom come from many sources and develop the teacher candidates' knowledge base for handling book challenges. It is always best to discuss the right to read controversial materials before a challenge becomes colored by the emotions of adults in various roles. If there is a gap in policy or procedures about handling book challenges, the school teachers can discover it and make the needed corrections (Maycock, 2011).

Teaching collaboratively relies on our trust in each person's expertise, planning carefully (but quickly!) together based on experiences with past classes and personalities, and taking the time to discuss changes to help students after each session. Darcy creates a special reaction sheet and shares both her class evaluations and the reaction sheets with Nadean as they refine the activities and clarify objectives. As with most teaching, the time to lecture is shortened and the time to interact (role plays, quizzes, sorting activities, student discussion) has increased to create a sense of discovery among the students. Our expertise is still ready when questions are raised but we no longer feel the need to present "everything" about the topic. The role plays remain the culminating activity that truly shows what the students have learned about intellectual freedom to read but also demonstrates the teacher candidates' ability to present reasons for book selection, and reading methods.

Our work together as education librarian and reading faculty helps teacher candidates develop their proactive powers around sensitive issues in young adult literature, and encourages them to not only read widely for themselves but also for their future students. Our working relationship is also an effective model for collaboration with others in a school setting, and often leads us to other topics to explore together. In the end, however, we want more educators to understand the important role of intellectual freedom and Freedom to Read. These rights are part of our democratic heritage and important for all readers. Further information and resources are available at http://sites.google.com/site/onlineintellectualfreedom

\section{References}

Adams, H. R. (2011). Solo librarians and intellectual freedom: Perspectives from the field. Knowledge Quest, 40(2), 30-35.

Adams, H. R. (2009). Advocating for intellectual freedom with principals and teachers. School Library Media Activities Monthly 25(6), 54.

American Bookseller's Foundation for Free Expression. (2001). KidsSpeak: Where kids speak for free speech. Retrieved from http://www.kidspeakonline.org/iq.html

American Library Association (2011). Number of challenges by year, reason, initiator, and institution (19902010). Retrieved from

http://www.ala.org/ala/issuesadvocacy/banned/frequentlychallenged/challengesbytype/index.cfm

American Library Association. (2008). Code of ethics. Retrieved from http://www.ala.org/ala/aboutala/offices/oif/ifgroups/cope/Code\%20of\%20Ethics\%202008.pdf

American Library Association. (n.d.). Terms and definitions. Retrieved from http://www.ala.org/ala/issuesadvocacy/banned/aboutbannedbooks/termsanddefinitions/index.cfm

Clapper, T. C. (2010.) Role play and simulation: Returning to teaching for understanding. Education Digest 75(8), 39-43.

Common Core State Standards Initiative (n.d.). Retrieved from http://www.corestandards.org/the-standards

Dear Mr. Chris Crutcher (2007). In Kaywell, J. (Ed.) Dear Author: Letters of Hope. (59-65). New York: Philomel Books.

First Amendment Schools. (n.d.). First amendment 101. Retrieved from http://www.firstamendmentschools.org/firstamendment101/

Illinois First Amendment Center. (n.d.). First amendment center fun activities. Retrieved from http://www.illinoisfirstamendmentcenter.com/activities.php 
John S. \& James T. Knight Foundation. (n.d.). Helping tomorrow's citizen's find their voice: Teach the first amendment. Retrieved from http://www.teachfirstamendment.org/

Kastner, A. \& Allen, R. (2002). Feasting on forbidden fruit: How to talk to teens about censorship. Teacher Librarian 30(2), 18-20.

Maycock, A. (2011). Issues and trends in intellectual freedom for teacher librarians. Teacher Librarian, 39(1), 8-12.

Meyer, N. (2007). September at school: Connecting constitution day with freedom to read. VOYA, 30(4) $310-2$.

National Coalition Against Censorship. (n.d.). Kid's right to read project. Retrieved from http://www.ncac.org/p.php?rel=3929

National Council of Teachers of English. (2010). Rationales for teaching challenged books. Retrieved from http://www.ncte.org/action/anti-censorship/rationales

Pennac, D. (2006). The rights of readers. Walker Books. Retrieved from http://www.walker.co.uk/bookshelf/the-rights-of-the-reader-poster.aspx

Reading specialist 0300: Test at a glance. (2009). Educational Testing Service. Available at http://www.ets.org/Media/Tests/PRAXIS/pdf/0300.pdf

Rosenblatt, L. M. (1994). The reader, the text, the poem: The transactional theory of the literary work. Carbonale, IL: Southern Illinois University Press.

Scales, P., \& American Library Association. (2009). Protecting intellectual freedom in your school library: Scenarios from the front lines. Chicago, IL: American Library Association.

Sutton, R. (2008). An interview with Pat Scales. Horn Book 84 (5), 489-99.

van Ments, M. (1999). The effective use of role-play: Practical techniques for improving learning. (2nd ed.). London: Kogan Page.

Nadean Meyer, MLS

Learning Resources Librarian

Eastern Washington University

nmeyer@ewu.edu

509-359-4262

LIB 100816 F Street Cheney, WA 99004

Darcy Bradley, PhD

Assistant Professor of Literacy

Eastern Washington University

Darcy.bradley@ewu.edu 